\title{
基于苯亚甲基丙二腈 $\mathrm{D}-\pi-\mathrm{A}$ 型化合物纳米粒子的 $\mathrm{Fe}^{3+}$ 亲水苂光探针
}

\author{
刘 幸 ${ }^{a}$ 陶 鹏 ${ }^{b, d}$ 杨晶晶 ${ }^{a}$ 刘 雯 ${ }^{a}$ 王 华 $*, a$ \\ 王学宁 ${ }^{c}$ 赵 强 ${ }^{d}$ 黄维扬 $^{b}$ 许并社 $* a$ \\ $\left({ }^{a}\right.$ 太原理工大学 新材料界面科学与工程教育部重点实验室 山西太原 030024) \\ ( ${ }^{b}$ 香港理工大学应用生物与化学技术系 香港 999077) \\ ( ${ }^{c}$ 山西白求恩医院(山西医学科学院) 心脏大血管外科 山西太原 030032) \\ ( $d$ 南京邮电大学 有机电子与信息显示国家重点实验室培育基地 南京 210023)
}

\begin{abstract}
摘要 制备了一种以三苯胺、辛基荡和丙二腈分别作为给体、 $\pi$ 桥和受体基团的扭转型 $\mathrm{D}-\pi-\mathrm{A}$ 结构的用于检测 $\mathrm{Fe}^{3+}$ 离 子的纳米颗粒(TA-DF-BDM/PSMA NPs)苂光探针. TA-DF-BDM/PSMA NPs 具有 $610 \mathrm{~nm}$ 红光发射, 并具有大的斯托克 斯位移(203 nm 左右). TA-DF-BDM/PSMA NPs 可在纯水中检测 $\mathrm{Fe}^{3+}$, 并具有较高的选择性和灵敏度以及低的检出限 $(0.9883 \mu \mathrm{mol} / \mathrm{L})$. 更重要的是 TA-DF-BDM/PSMA NPs 具有稳定的光物理性质, 并且具有可逆性、较好的生物相容性和 较低的细胞毒性, 使其可应用于生物成像研究.
\end{abstract}

关键词 苂光探针; $\mathrm{Fe}^{3+}$ 离子; 亲水性; 可逆性

\section{Hydrophilic Fluorescent Probes for $\mathrm{Fe}^{3+}$ lons Based on Nanoparticles of Twisting D-T-A Type Compound Derived from Benzylidenemalononitrile}

Liu, Xing ${ }^{a} \quad$ Tao, Peng ${ }^{b, d} \quad$ Yang, Jingjing ${ }^{a} \quad$ Liu, Wen $^{a} \quad$ Wang, Hua ${ }^{*, a}$ Wang, Xuening ${ }^{c} \quad{\text { Zhao, } \text { Qiang }^{d} \quad \text { Wong, Wai-yeung }}^{b} \quad$ Xu, Bingshe ${ }^{*, a}$

$\left({ }^{a}\right.$ Key Laboratory of Interface Science and Engineering in Advanced Materials of Ministry of Education, Taiyuan University of Technology, Taiyuan, Shanxi 030024)

( ${ }^{b}$ Department of Applied Biology and Chemical Technology, The Hong Kong Polytechnic University, Hong Kong 999077) ( ${ }^{c}$ Department of Cardiovascular Surgery, Shanxi Baiqiuen Hospital (Shanxi Academy of Medical Sciences), Taiyuan, Shanxi 030032)

$\left({ }^{d}\right.$ Key Laboratory for Organic Electronics and Information Displays and Institute of Advanced Materials, Nanjing University of Posts and Telecommunications (NUPT), Nanjing 210023)

\begin{abstract}
In this work, the novel fluorescent probes for detecting $\mathrm{Fe}^{3+}$ ions based on nanoparticles (TA-DF-BDM/PSMA NPs) of fluorescence material with twisting D- $\pi$-A configuration was designed and prepared, in which triphenylamine (TA), 9,9-dioctylfluorene (DF) and benzylidenemalononitrile (BDM) serve as electron donor (D) unit, $\pi$ conjugated unit, and electron acceptor (A) unit, respectively. TA-DF-BDM/PSMA NPs exhibit red-emission peak located at $610 \mathrm{~nm}$ in photoluminescence spectrum and larger stokes shifts ( $c a .203 \mathrm{~nm}$ ). And, TA-DF-BDM/PSMA NPs exhibit high selectivity for detecting $\mathrm{Fe}^{3+}$ ions in pure water with high sensitivity and low detection limit of $0.9833 \mu \mathrm{mol} / \mathrm{L}$. More importantly, TA-DFBDM/PSMA NPs show such properties as good photophysical stability, reversibility, excellent biocompatibility and low cytotoxicity, which can be utilized in bioimaging investigations.
\end{abstract}

Keywords fluorescent probes; $\mathrm{Fe}^{3+}$ ions; hydrophilcity; reversibility

* Corresponding authors. E-mail: wanghua001@tyut.edu.cn; xubs@tyut.edu.cn

Received November 4, 2019; revised January 27, 2020; published online April 9, 2020.

Project supported by the National Natural Scientific Foundation of China (Nos. 61775155, 61605138, 61705156, 61905120), the Shanxi Provincial Key Innovative Research Team in Science and Technology (No. 201601D021043), and the Hong Kong Polytechnic University (No. 1-ZE1C and 847S).

国家自然科学基金(Nos. 61775155, 61605138, 61705156, 61905120)、山西省科技创新重点团队(No. 201601D021043)、香港理工大学(Nos. 1-ZE1C, 847S) 资助项目. 


\section{Introduction}

As one of the most essential elements in biological systems of human body, the $\mathrm{Fe}^{3+}$ ions perform crucial role in oxygen carrying capacity and act as a cofactor in many enzymatic electron transfer as well as oxidation reactions ${ }^{[1,2]}$. One hand, deficiency in $\mathrm{Fe}^{3+}$ ions could cause degradation of oxygen transportation in cells, especially in anemia, liver damage, diabetes, and cancers. ${ }^{[3 \sim 5]}$ The other hand, excessive accumulation of $\mathrm{Fe}^{3+}$ ions in cells causes a Fenton reaction, resulting in generation of reactive oxygen species (ROS) which is the major aetiological factors for Alzheimer's disease or Parkinson's disease. ${ }^{[6 \sim 8]}$ Thus, the qualitative and quantitative analysis of $\mathrm{Fe}^{3+}$ ions is of great significance in clinical medical applications. ${ }^{[9]}$

At present, conventional detection methods of $\mathrm{Fe}^{3+}$ ions include voltammetry, atomic absorption spectrometry and inductively coupled plasma mass spectrometry. ${ }^{[10 \sim 13]}$ However, these methods suffer from such problems as destruction of testing samples and interference by other ions during testing. Recently, fluorescent probe technology has been considered as one of the most effective detection methods of microelements in human body due to good selectivity, high sensitivity, low detection limits, capability of both in vitro and in vivo detections and facile instrument operability. ${ }^{[14 \sim 17]}$ Especially, the rapid development in confocal fluorescence microscopy and optical imaging push forward the application process of fluorescent probe technology in biomedical field.

Till now, many kinds of fluorescent probes for $\mathrm{Fe}^{3+}$ ions have been reported. For example, the rhodamine derivate fluorescent probes, benzimidazoquinoline derivate fluorescent probes, benzimidazole derivate fluorescent probes. ${ }^{[18 \sim 20]}$ However, current fluorescent probes for $\mathrm{Fe}^{3+}$ ions are limited by several disadvantages, e.g. small Stokes shift, poor performance for detections in pure water, and worse interference immunity of other ions. For example, the cross-sensitivity of $\mathrm{Cu}^{2+}$ and $\mathrm{Al}^{3+}$ ions during the $\mathrm{Fe}^{3+}$ ions detection is very difficult to eliminate, which is owing to analogous ion size of $\mathrm{Fe}^{3+}$ ions. ${ }^{[6,21]}$ In addition, the working medium of current fluorescent probes for $\mathrm{Fe}^{3+}$ ions is usually mainly composed of organic solvents, which can damage microorganisms, destroy cellular structure functional integrity, inhibit cell growth and even lead to cell death. ${ }^{[22]}$ Hence, it is necessary for designing and preparing hydrophilic fluorescent probe for $\mathrm{Fe}^{3+}$ ions with high selectivity. Furthermore, the reversibility ability of the fluorescent probes is one of the important properties for $\mathrm{Fe}^{3+}$ ions detection applications. Hence, it is necessary for designing and preparing hydrophilic and reversible fluorescent probe with high selectivity.

Herein, we report a novel reversible fluorescent probe for detection of $\mathrm{Fe}^{3+}$ ions, which is composed of nanoparticles derived from fluorescence material of TA-DF-PDM. It exhibits high selectivity for $\mathrm{Fe}^{3+}$ ions in pure water, high sensitivity with detection limit of $0.9833 \mu \mathrm{mol} / \mathrm{L}$, excellent biocompatibility and low cytotoxicity.

\section{Results and discussion}

\subsection{Morphology of TA-DF-BDM/PSMA NPs}

The diameter distributions of TA-DF-BDM/PSMA NPs were characterized by dynamic light scattering (DLS). As shown in Figure 1a, the average diameter of TA-DFBDM/PSMA NPs is estimated to be $64 \mathrm{~nm}$. And, the morphology of the TA-DF-BDM/PSMA NPs in aqueous solution was observed by transmission electron microscope (TEM). As expressed in Figures 1c and 1d, the grain shape of TA-DF-BDM/PSMA NPs is nearly sphere with average diameter of about $50 \mathrm{~nm}$, which is slightly smaller than that obtained using DLS method. It is because that hydrodynamic diameter of the nanoparticles measured by DLS is usually larger than their size obtained by TEM. ${ }^{[23]}$ Furthermore, the DPI data (0.136) exhibits good hydrophilicity and dispersibility, which retain absence of nanoparticles aggregation in water even after being stored for months. In addition, the zeta potential of the TA-DF-BDM/ PSMA NPs was $-23.3 \mathrm{mV}$ (Figure $1 \mathrm{~b}$ ). For comparison, the PSMA-free TA-DF-BDM NPs was also prepared, which exhibited the zeta potential of $-0.716 \mathrm{mV}$. It is suggested that the PSMA successfully incorporated into TA-DFBDM and formed stable nanoparticles of TA-DF-BDM/ PSMA NPs.

\subsection{Photophysical properties of TA-DF-BDM/PSMA NPs}

The molecule of TA-DF-BDM is constructed with twisting D- $\pi$-A configuration, in which triphenylamine (TA), 9,9-dioctylfluorene (DF) and benzylidenemalononitrile (BDM) serve as electron donor (D) unit, $\pi$ conjugated unit, and electron acceptor (A) unit, respectively. TA-DF-BDM realizes blue-light emission by charger transfer from $\mathrm{D}$ unit of TA to A unit of BDM. As shown in Figure 2a, the UV-vis absorption spectrum of TA-DF-BDM exhibits absorption band at $350 \sim 420 \mathrm{~nm}$, which attributes to charge transfer from TA to BDM. It induces in blue-light emission peak $\left(\lambda_{\mathrm{PL}}\right)$ located at $450 \mathrm{~nm}$ in PL spectrum of TA-DFBDM. But, it can be found that the UV-vis absorption spectrum and PL spectrum of TA-DF-BDM show rather bigger overlap, which lead to self-absorption phenomenon. Additional, due to smaller Stokes shifts (ca. $26 \mathrm{~nm}$ ), the blue-light emission of TA-DF-BDM will easily be interfered with background noise from excitation source during fluorescence imaging. ${ }^{[23 \sim 25]}$

To solve above problem, the TA-DF-BDM/PSMA NPs were fabricated by reprecipitation method. It was known that the nanoparticles of fluorescence molecules can lead to bigger red-shift of emission peak relative to fluorescence molecules, owing to molecular accumulation. So, it can be seen from Figure $2 b$ that the $\lambda_{\mathrm{PL}}$ of TA-DF-BDM/ PSMA NPs shows bathochromic shift from $450 \mathrm{~nm}$ to 608 $\mathrm{nm}$, which separates with its UV-vis absorption spectrum totally. It expresses rather larger Stokes shifts ( $c a .210$ nm). ${ }^{[24]}$ Furthermore, the TA-DF-BDM/PSMA NPs were fabricated by reprecipitation method, which will also im- 

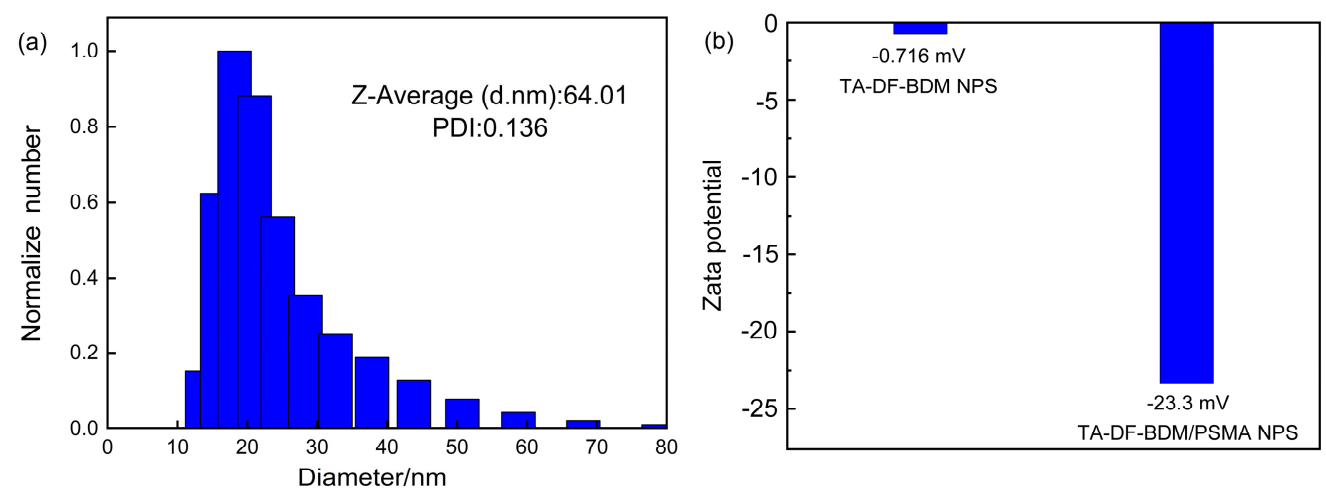

(c)

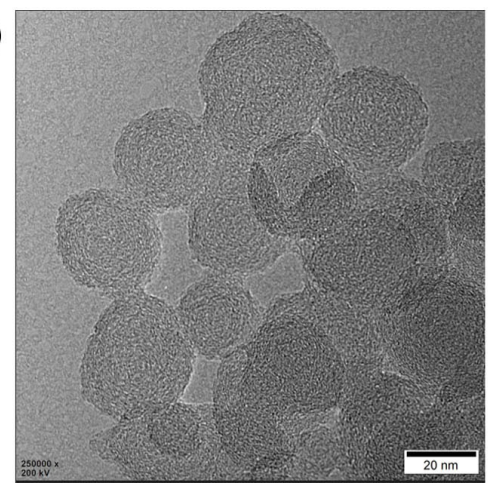

(d)

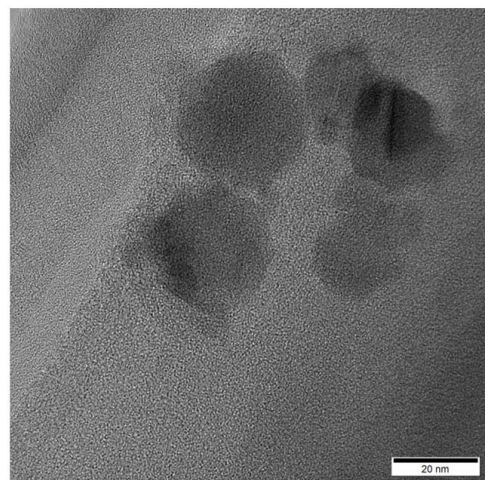

Figure 1 (a) DLS of TA-DF-BDM/PSMA NPs in aqueous solution, (b) comparison of zeta potentials of TA-DF-BDM NPs and TA-DF-BDM/PSMA NPs in aqueous solution, (c) TEM image of TA-DF-BDM NPs, and (d) TEM image of TA-DF-BDM/PSMA NPs
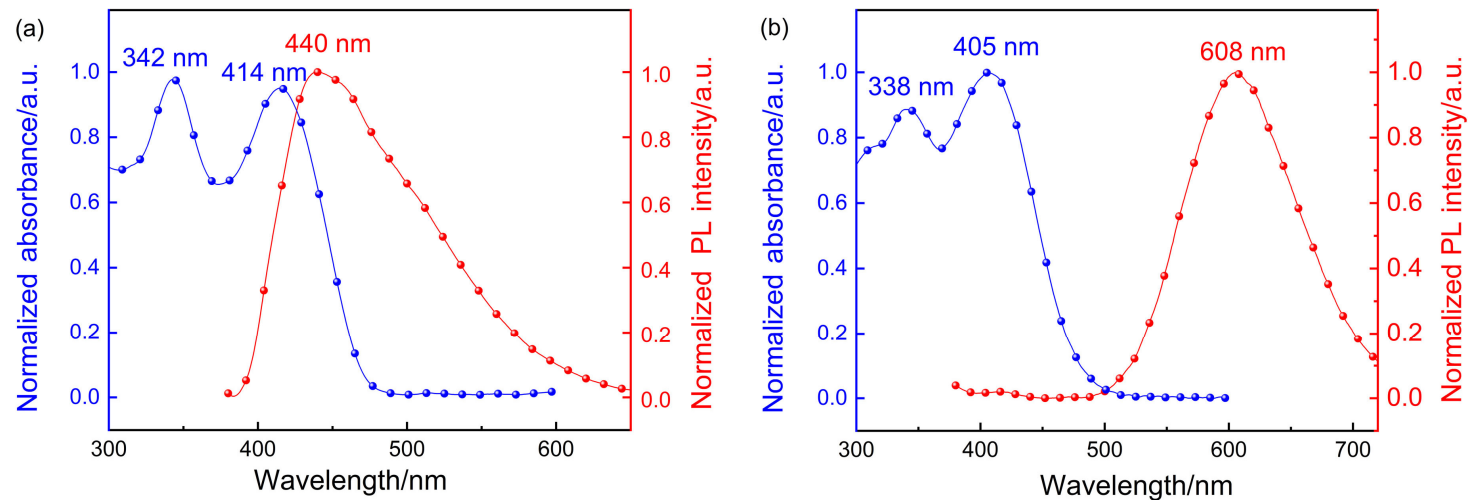

Figure 2 UV-vis absorption spectra and PL spectra

(a) TA-DF-BDM in THF; (b) TA-DF-BDM/PSMA NPs in aqueous solution

prove hydrophilicity and dispersibility for satisfying requirement for biological measurement environment.

\subsection{Photophysical stability of TA-DF-BDM/PSMA NPs}

The $\mathrm{pH}$ values of different human organisms are quite different, which range from weak acidic in the lysosome and endosome $(\mathrm{pH}=4.7 \sim 6.5)$ to weak basic in active mitochondria $(\mathrm{pH}=8.0) .{ }^{[25]}$ Hence, the photophysical properties TA-DF-BDM/PSMA NPs need to be stable in measurement scenes with different $\mathrm{pH}$ value. For testifying it, the PL spectra of TA-DF-BDM/PSMA NPs in solutions with different $\mathrm{pH}$ value were recorded. As shown in Figure 3 , the PL spectra of TA-DF-BDM/PSMA NPs show no variation with increasing $\mathrm{pH}$ values from 4 to 11 , for example, the $\lambda_{\mathrm{PL}}$ and emission intensity. It is indicated excel- lent photophysical stability of TA-DF-BDM/PSMA NPs in different $\mathrm{pH}$ value ${ }^{[26]}$.

\subsection{Fluorescence response to metal ions}

Selectivity is an essential prerequisite to evaluate a fluorescent probe before its practical application. To evaluate selectivity of TA-DF-BDM/PSMA NPs for $\mathrm{Fe}^{3+}$ ions, the PL spectra of TA-DF-BDM/PSMA NPs in aqueous solutions with presence of common environmental metal ions (i.e. $\mathrm{Fe}^{3+}, \mathrm{Zn}^{2+}, \mathrm{Ag}^{2+}, \mathrm{Fe}^{2+}, \mathrm{Co}^{2+}, \mathrm{Na}^{+}, \mathrm{Pb}^{2+}, \mathrm{Hg}^{2+}, \mathrm{Ni}^{2+}$, $\mathrm{Cd}^{2+}, \mathrm{Mn}^{2+}, \mathrm{Ba}^{2+}, \mathrm{Cu}^{2+}, \mathrm{Mg}^{2+}, \mathrm{Ca}^{2+}, \mathrm{K}^{+}, \mathrm{Al}^{3+}$ ) were recorded, respectively. ${ }^{[22,29]}$

The UV absorbance spectra of TA-DF-BDM/PSMA NPs $(10 \mu \mathrm{mol} / \mathrm{L})$ in the presence of different metal ions (1 equiv.) in aqueous solution were shown in Figure 4a. It is obvious that, in the absorption peaks, there was no evident 


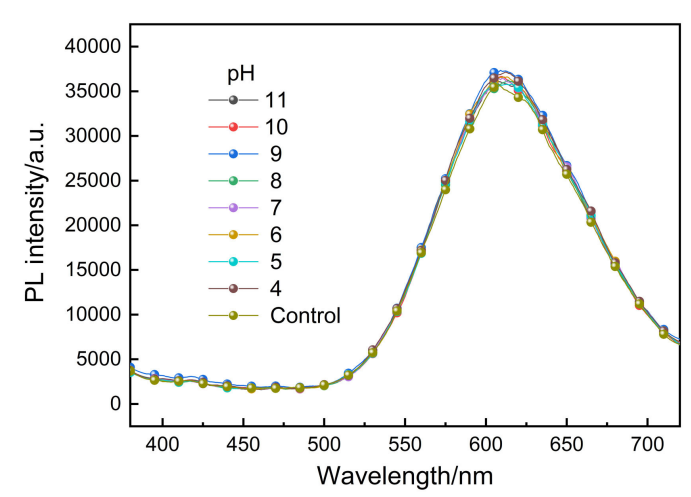

Figure 3 PL spectra of TA-DF-BDM/PSMA NPs in solutions with different $\mathrm{pH}$ value
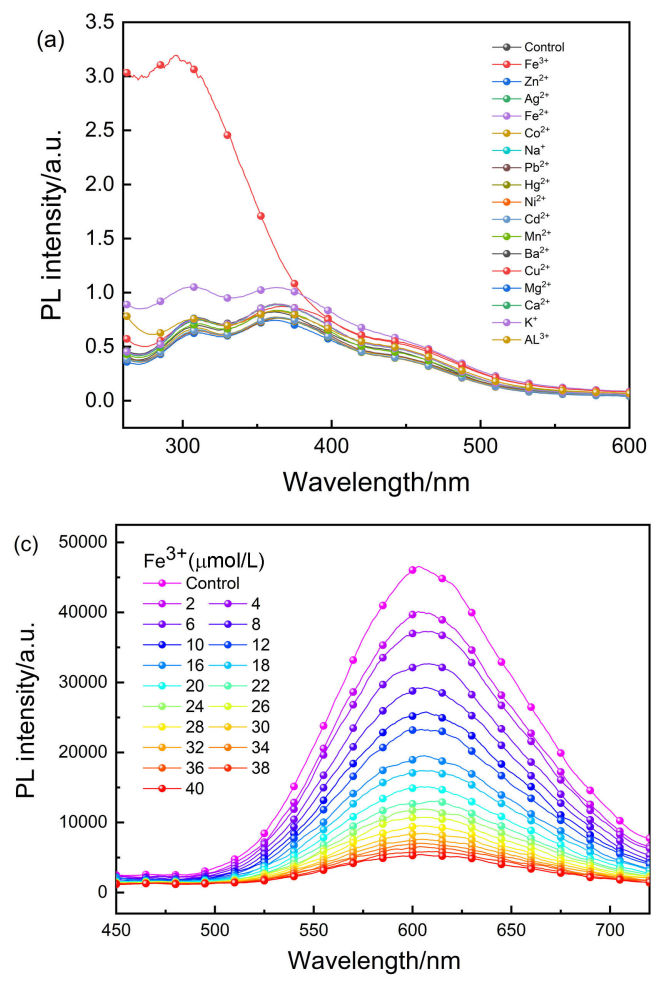

change except for $\mathrm{Fe}^{3+}$ ions. As shown in Figure $4 \mathrm{~b}$, the $\lambda_{\mathrm{PL}}$ located at around $610 \mathrm{~nm}$ corresponding to red emission of TA-DF-BDM/PSMA NPs is nearly vanished upon addition of $\mathrm{Fe}^{3+}$ ions, which distinguishes with other ions. Hence, it is can be drawn that only $\mathrm{Fe}^{3+}$ ions can quench red-emission of TA-DF-BDM/PSMA NPs, however, other metal ions including $\mathrm{Cu}^{2+}$ ions exhibit no quenching phenomenon. It is suggested that TA-DF-BDM/PSMA NPs possess excellent selectivity for detecting $\mathrm{Fe}^{3+}$ ions in potential.

Furthermore, the fluorescence quenching behavior of $\mathrm{Fe}^{3+}$ ions was studied using fluorescence titration at fixed concentration of TA-DF-BDM/PSMA NPs with varying
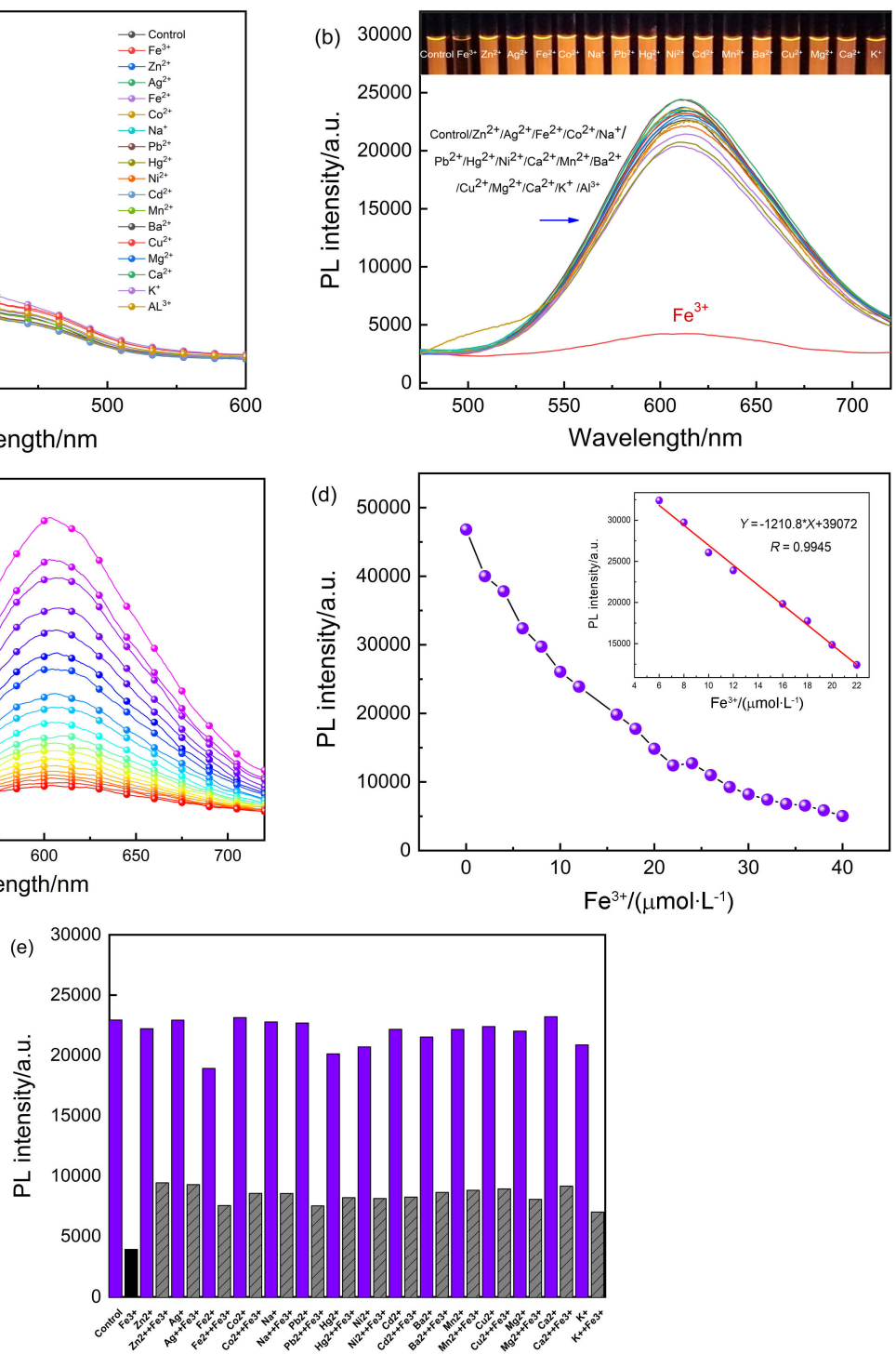

Figure 4 (a) UV absorbance and (b) PL spectra and photographs under UV lamp (365 nm) of TA-DF-BDM/PSMA NPs (10 $\mu$ mol/L) in the presence of different metal ions (1 equiv.) in aqueous solution; From left to right are $\mathrm{Fe}^{3+}, \mathrm{Zn}^{2+}, \mathrm{Ag}^{2+}, \mathrm{Fe}^{2+}, \mathrm{Co}^{2+}, \mathrm{Na}^{+}, \mathrm{Pb}^{2+}, \mathrm{Hg}^{2+}$, $\mathrm{Ni}^{2+}, \mathrm{Cd}^{2+}, \mathrm{Mn}^{2+}, \mathrm{Ba}^{2+}, \mathrm{Cu}^{2+}, \mathrm{Mg}^{2+}, \mathrm{Ca}^{2+}, \mathrm{K}^{+}$in the illustration; (c) PL spectra of TA-DF-BDM/PSMA NPs $(25 \mu \mathrm{mol} / \mathrm{L})$ exposed to various concentration of $\mathrm{Fe}^{3+}$ ions in aqueous solution; (d) fluorescence titration curve of TA-DF-BDM/PSMA NPs $(25 \mu \mathrm{mol} / \mathrm{L})$ with $\mathrm{Fe}^{3+}$ in aqueous solution, inset: the relationship between emission peak intensity and $\mathrm{Fe}^{3+}$ ions concentration; (e) PL intensity at $610 \mathrm{~nm}$ of TA-DF-BDM/PSMA NPs $(10 \mu \mathrm{mol} / \mathrm{L})$ exposed to 1.00 equiv. of various metal ions and mixtures of 1.00 equiv. of Fe $\mathrm{e}^{3+}$ with 1.00 equiv. of other metal ions in aqueous solution 
concentrations of $\mathrm{Fe}^{3+}$ ions. As expressed in Figure 4c, the PL intensity of red emission peak of TA-DF-BDM/PSMA NPs degrades with increasing $\mathrm{Fe}^{3+}$ ions concentration, which is almost fully quenched when the concentration of $\mathrm{Fe}^{3+}$ ions rises above $40 \mu \mathrm{mol} / \mathrm{L}$. Under low concentrations of $\mathrm{Fe}^{3+}$ ions $(6 \sim 22 \mu \mathrm{mol} / \mathrm{L})$, the PL intensity of emission peak decreases rapidly and exhibits good linear ( $R=0.9945)$ relationship with concentrations of $\mathrm{Fe}^{3+}$ ions (Figure 4d). Hence, it is deduced that TA-DF-BDM/ PSMA NPs can act as fluorescent probe for quantitative detection of microscale $\mathrm{Fe}^{3+}$ ions. And, the detection limit was calculated from the equation $\mathrm{DL}=3 \delta / k$, where $\delta$ is the standard deviation of the blank measurement and $k$ is the slope between emission peak intensity versus $\mathrm{Fe}^{3+}$ ions concentration. The detection limit of TA-DF-BDM/PSMA $\mathrm{NPs}$ for $\mathrm{Fe}^{3+}$ ions is $0.9833 \mu \mathrm{mol} / \mathrm{L}$.

To investigate the interference of other metal ions, $\mathrm{Fe}^{3+}$ ions were detected by TA-DF-BDM/PSMA NPs in presence of different ions. The PL spectra of TA-DF-BDM/ PSMA NPs were further measured in complicated systems in the presence of $\mathrm{Fe}^{3+}$ ions mixed with 1.00 equiv. of $\mathrm{Fe}^{3+}, \mathrm{Zn}^{2+}, \mathrm{Ag}^{2+}, \mathrm{Fe}^{2+}, \mathrm{Co}^{2+}, \mathrm{Na}^{+}, \mathrm{Pb}^{2+}, \mathrm{Hg}^{2+}, \mathrm{Ni}^{2+}, \mathrm{Cd}^{2+}$, $\mathrm{Mn}^{2+}, \mathrm{Ba}^{2+}, \mathrm{Cu}^{2+}, \mathrm{Mg}^{2+}, \mathrm{Ca}^{2+}, \mathrm{K}^{+}, \mathrm{Al}^{3+}$ ions, respectively. As shown in Figure 4e, when other ions were added, the PL intensity of emission peak at $610 \mathrm{~nm}$ did not change much. The PL intensity decreased obviously after dropping of $\mathrm{Fe}^{3+}$ ions. To investigate the effect of $\mathrm{pH}$ on $\mathrm{Fe}^{3+}$ detection, furthermore, we test the change of the solution fluorescence intensity adding the $\mathrm{Fe}^{3+}$ under variety of the pH. All these results confirm that the detection of TA-DF-BDM/PSMA NPs to $\mathrm{Fe}^{3+}$ ions is exclusive, which possesses a potential to be applied in practice.

\subsection{Binding mode of TA-DF-BDM with $\mathrm{Fe}^{3+}$ ions}

$\mathrm{The} \mathrm{Fe}^{3+}$ ion is a type of paramagnetic metal ion, and its complex with TA-DF-BDM can affect the proton signals close to the $\mathrm{Fe}^{3+}$ binding site. As shown in Figure 5, the data revealed that proton signal of $\mathrm{H}_{\mathrm{a}}$ at $\delta 8.589$ shifted upfield to $\delta 8.550$ and became board after the addition of 1.00 equiv. of $\mathrm{Fe}^{3+}$ ions. This might be attributed to coordination reaction between $\mathrm{Fe}^{3+}$ ions and malononitrile of BDM unit in TA-DF-BDM, which can frustrate twisting $\mathrm{D}-\pi-\mathrm{A}$ configuration and restrain emission originating from charge transfer from TA to BDM. ${ }^{[27]}$

To determine the stoichiometry of TA-DF-BDM and $\mathrm{Fe}^{3+}$ ion, Job's method was employed. A series of mixture solutions of TA-DF-BDM and $\mathrm{Fe}^{3+}$ ion with various molar fractions were prepared by keeping the total TA-DF$\mathrm{BDM}$ and $\mathrm{Fe}^{3+}$ ion concentration constant of $10 \mu \mathrm{mol} /$ L. ${ }^{[28,29]}$ The PL in intensity of emission peak at $450 \mathrm{~nm}$ was recorded for each solution. As expressed in Figure 6, it was found that the maximum PL intensity was observed when the molar fraction of $\mathrm{Fe}^{3+}$ ions reached 0.48 , indicating that $1: 1$ stoichiometry for the complex of TA-DF-BDM to $\mathrm{Fe}^{3+}$ ions. It is owning to coordination reaction between $\mathrm{Fe}^{3+}$ ions with malononitrile of BDM unit.

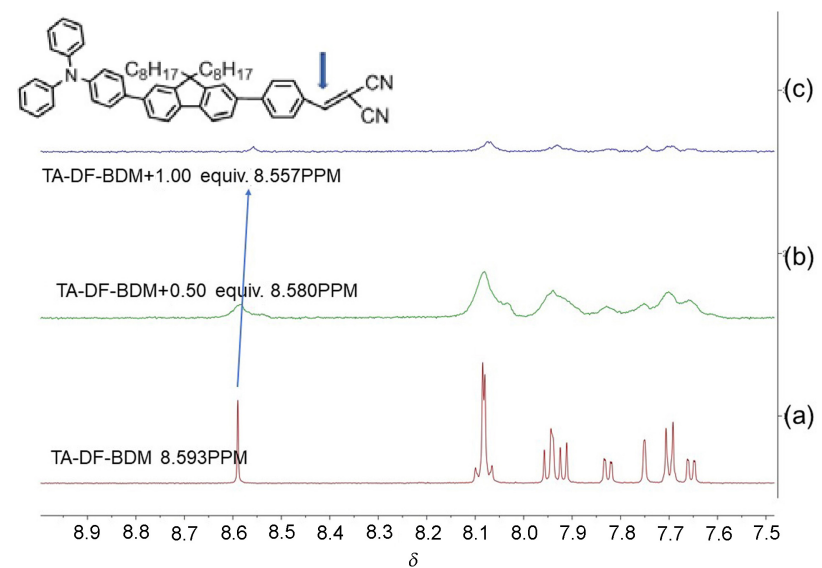

Figure $5{ }^{1} \mathrm{H}$ NMR spectra in DMSO- $d_{6}$ of (a) TA-DF-BDM, (b) TA-DF-BDM +0.50 equiv. of $\mathrm{Fe}^{3+}$, and (c) TA-DF-BDM +1.00 equiv. of $\mathrm{Fe}^{3+}$

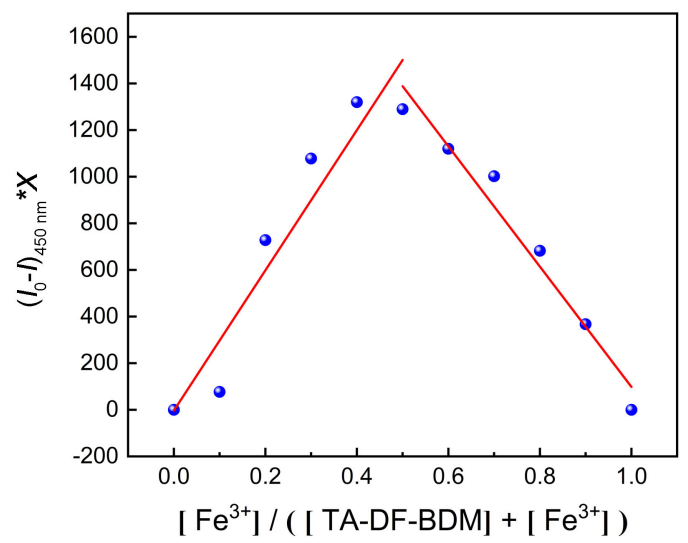

Figure 6 Job's plot of TA-DF-BDM for $\mathrm{Fe}^{3+}$ in aqueous solution

$[$ TA-DF-BDM $]+\left[\mathrm{Fe}^{3+}\right]=10 \mu \mathrm{mol} / \mathrm{L} . \mathrm{X}$ is the molar fraction of TA-DFBDM, $I_{0}$ and $I$ indicate the emission intensity at $450 \mathrm{~nm}$ before and after addition of $\mathrm{Fe}^{3+}$ ions, respectively

\subsection{Fluorescence reversibility of TA-DF-BDM/PSMA NPs}

The $200 \mu \mathrm{L}$ of aqueous solution of $\mathrm{Fe}^{3+}$ ions with concentration of $10 \mu \mathrm{mol} / \mathrm{L}$ was injected into aqueous solution of TA-DF-BDM/PSMA NPs (names as Solution S-NP) to acquire solution S-NP-Fe. By comparing with PL spectra of solutions of S-NP and S-NP-Fe in Figure 7a, it can be found that the emission peak located at $610 \mathrm{~nm}$ corresponding to TA-DF-BDM/PSMA NPs vanished after injection of $\mathrm{Fe}^{3+}$ ions, which had been identified as above work. Then, $200 \mu \mathrm{L}$ of $L$-ascorbic acid aqueous solution with concentration of $0.28 \mu \mathrm{mol} / \mathrm{L}$ was injected into solution S-NP-Fe to acquire solution S-NP-Fe-LAA. Then, it was observed that the emission peak located at $610 \mathrm{~nm}$ appeared again after injection of $L$-ascorbic acid. So, it is suggested the TA-DF-BDM/PSMA NPs have good reversibility of fluorescence probes for detection of $\mathrm{Fe}^{3+}$ ions. According to the reversibility of the fluorescent probe, it can be expected that composite probe of solution S-NP-Fe can also be used to detect $L$-ascorbic acid qualita- 
tively and quantitatively as expressed in Figure $7 \mathrm{~b}$.
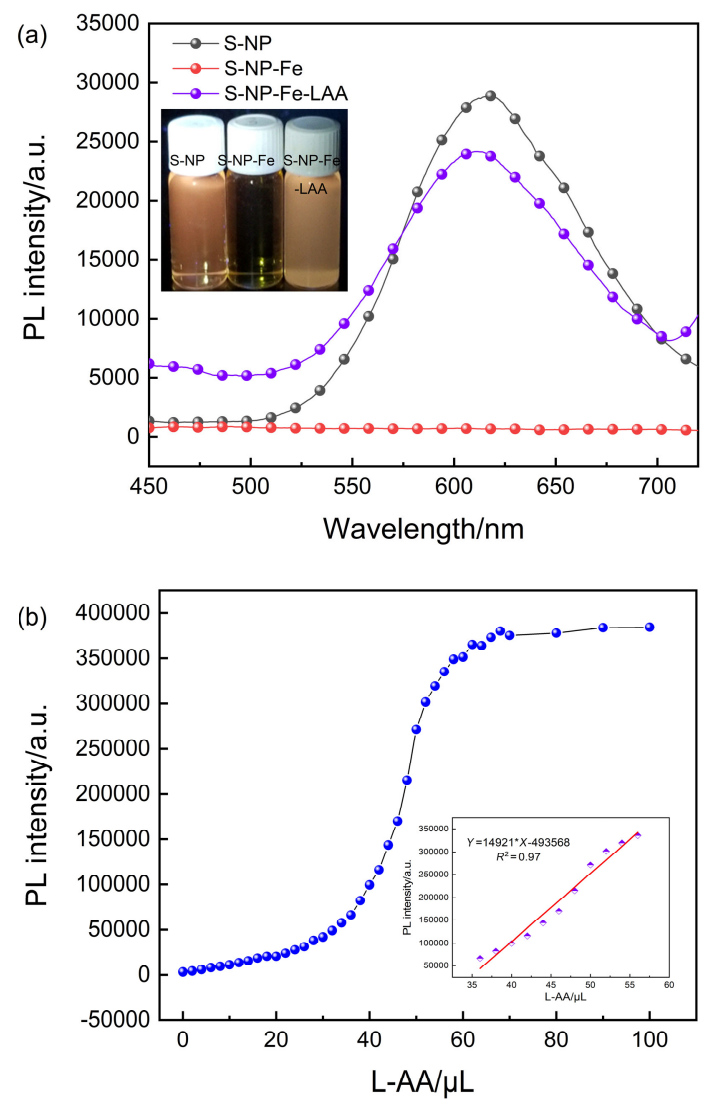

Figure 7 (a) Fluorescence reversibility of TA-DF-BDM/PSMA NPs and photographs of TA-DF-BDM/PSMA NPs under UV excitation; (b) fluorescence titration curve of TA-DF-BDM/ PSMA NPs $+\mathrm{Fe}^{3+}(10 \mu \mathrm{mol} / \mathrm{L})$ with LAA in aqueous solution Inset: the relationship between emission peak intensity and LAA concentration

For understanding the fluorescence reversibility, electron paramagnetic resonance (EPR) tests were carried on TA-DF-BDM/PSMA NPs. ${ }^{[30]}$ As shown in Figure 8a, the EPR spectrum of solution S-NP-Fe exhibits a strong paramagnetic signal in the area of $2500 \sim 3500 \mathrm{GS}$, due to paramagnetic effect $\mathrm{Fe}^{3+}$ ions. However, solution S-NPFe-LAA shows weaker paramagnetic signal. Upon addition of $L$-ascorbic acid, the paramagnetic signal of $\mathrm{Fe}^{3+}$ ions is weakened. It is because that $L$-ascorbic acid is a strong reducing agent that leads to transformation from $\mathrm{Fe}^{3+}$ ions to $\mathrm{Fe}^{2+}$ ions (as shown in Figure 8b).

\subsection{Detection of $\mathrm{Fe}^{3+}$ ions in human serum samples}

For evaluating the feasibility of TA-DF-BDM/PSMA NPs for detection $\mathrm{Fe}^{3+}$ ions in complex biological environment, the chemosensory based on TA-DF-BDM/PSMA NPs was challenged by human serum. ${ }^{[31]}$ After human serum samples were centrifuged and removed the protein precipitate, the supernatant was diluted 100 -fold with TrisHCI buffer $(10 \mathrm{mmol} / \mathrm{L}, \mathrm{pH}=7.19)$. Then, $150 \mu \mathrm{L}$ of aqueous solution containing TA-DF-BDM/PSMA NPs (20 $\mu \mathrm{mol} / \mathrm{L})$ and different concentration of $\mathrm{Fe}^{3+}$ ions dropped in $150 \mu \mathrm{L}$ of diluted human serum. The PL spectra of test-
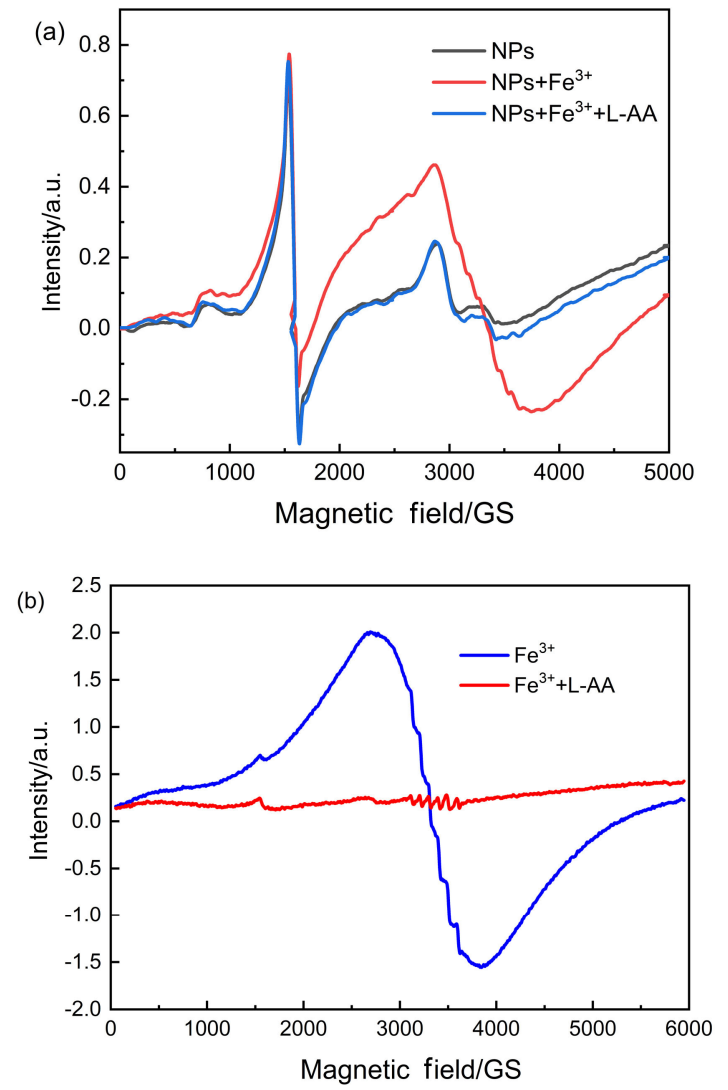

Figure 8 (a) EPR spectra of solution S-NP-Fe and solution S-NP-Fe-LAA, and (b) EPR spectra of solution S-Fe and solution S-Fe-LAA

ing sample were measured and the fluorescence titration curve was fitted. As shown in inset of Figure 9b, the unknown concentration of $\mathrm{Fe}^{3+}$ ions was obtained according to the relationship between the PL intensity of emission peak at $610 \mathrm{~nm}$ and concentration of $\mathrm{Fe}^{3+}$ ion. It can be seen from Table 1 that the recovery is in the range of $94.9 \% \sim 108.2 \%$ and the relative standard deviation (RSD, $n=5$ ) is less than $3.5 \%$, indicating high analytical precision of TA-DF-BDM/PSMA NPs.

\subsection{Cellular imaging}

The toxicity of TA-DF-BDM/PSMA NPs is a natural concern because of its potential for bioimaging. The cytotoxicity of TA-DF-BDM/PSMA NPs was evaluated by 3-(4,5-dimethylthiazol-2-yl)-2,5-diphenyltetrazolium bromide (MTT) assays using HeLa cells at various concentration for 24 h. $^{[27]}$ In Figure 10, the results show that TA-DF-BDM/PSMA NPs is nontoxic to the cultured cells under the experimental conditions. We also used HeLa cells as model cells to study the subcellular distributions of TA-DF-BDM/PSMA NPs by confocal fluorescence microscopy. Herein, cultured HeLa cells were incubated with TA-DF-BDM/PSMA NPs $(10 \mu \mathrm{mol} / \mathrm{L})$ for $30 \mathrm{~min}$ under $37{ }^{\circ} \mathrm{C}$. As predicted, confocal fluorescence microscopy images showed that TA-DF-BDM/PSMA NPs with fluorescence were cell membrane permeable as shown in Figure 11. In a control experiment, the cells were pretreated 

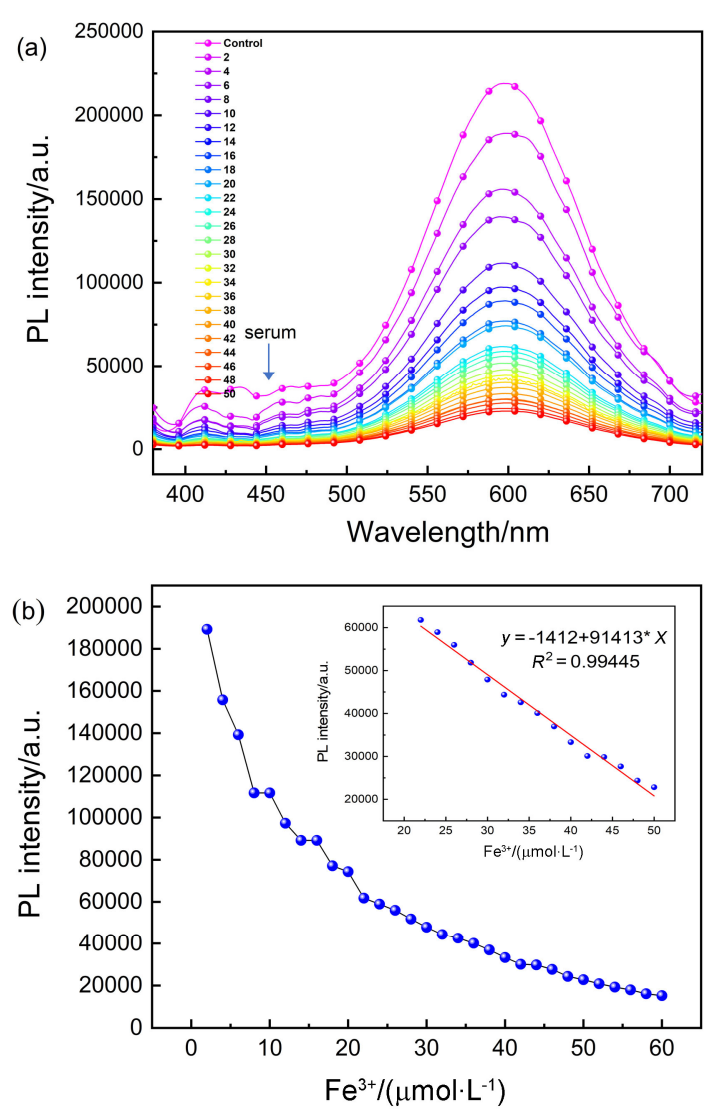

Figure 9 (a) PL spectra of TA-DF-BDM/PSMA NPs $(10 \mu \mathrm{mol} /$ $\mathrm{L}$ ) exposed to various concentration of $\mathrm{Fe}^{3+}$ ions in human serum; (b) fluorescence titration curve of TA-DF-BDM/PSMA NPs $(10 \mu \mathrm{mol} / \mathrm{L})$ with $\mathrm{Fe}^{3+}$ in human serum, inset: the relationship between PL intensity of emission peak at $610 \mathrm{~nm}$ and concentration of $\mathrm{Fe}^{3+}$ ions

Table 1 Testing results for the determination of $\mathrm{Fe}^{3+}$ ions in human serum samples

\begin{tabular}{lcccc}
\hline No. Added $/\left(\mu \mathrm{mol} \bullet \mathrm{L}^{-1}\right)$ & Found $/\left(\mu \mathrm{mol} \bullet^{-1}\right)$ & Recovery $/ \%$ & RSD $/ \%$ \\
\hline 1 & 10 & 10.83 & 108.2 & 2.9 \\
2 & 20 & 19.35 & 96.7 & 3.5 \\
3 & 26 & 24.68 & 94.9 & 1.8 \\
4 & 50 & 50.19 & 100.4 & 1.2 \\
\hline
\end{tabular}

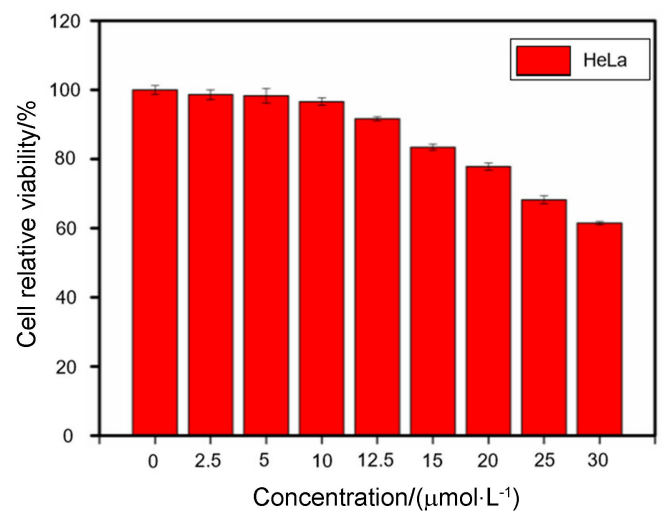

Figure 10 Cytotoxicity test of HeLa cells treated with various concentrations of TA-DF-BDM NPs after $24 \mathrm{~h}$

with TA-DF-BDM/PSMA NPs for $30 \mathrm{~min}$, and further incubated with $\mathrm{Fe}^{3+}(10 \mu \mathrm{mol} / \mathrm{L})$ for $30 \mathrm{~min}$, eliciting an obvious fluorescence decrease in the range of $550 \sim 650$ $\mathrm{nm}$, in agreement with the $\mathrm{Fe}^{3+}$ ions induced fluorescence response. The $L$-ascorbic acid was added to the cells incubate for $30 \mathrm{~min}$, and the fluorescence reversibility is at $550 \sim 650 \mathrm{~nm}$.

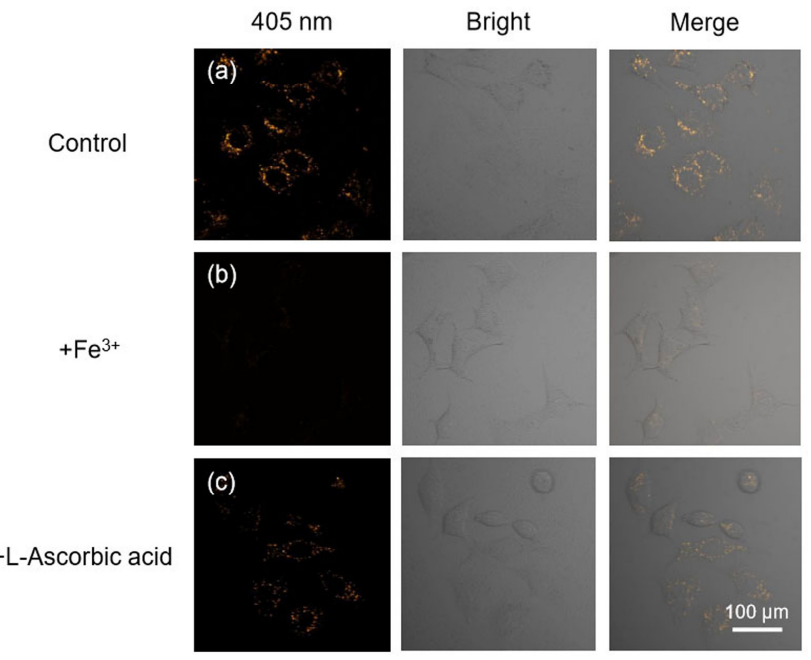

Figure 11 Fluorescence imaging of HeLa cells incubated with TA-DF-BDM/PSMA NPs $(10 \mu \mathrm{mol} / \mathrm{L})$ before (a) or after (b) addition of $\mathrm{Fe}^{3+}$ ions $(10 \mu \mathrm{mol} / \mathrm{L})$ and (c) addition of $L$-ascorbic acid

\section{Conclusions}

The reversible fluorescent probe for $\mathrm{Fe}^{3+}$ ions is prepared, i.e. TA-DF-BDM/PSMA NPs which is composed of nanoparticles based on fluorescence material of TA-DFBDM. In this work, the fluorescence material of TA-DFBDM was synthesized by Suzuki coupling reaction firstly, which was made into nanoparticles by reprecipitation method to acquire TA-DF-BDM/PSMA NPs. The spectral properties of TA-DF-BDM/PSMA NPs were discussed in detail. This fluorescence probe based on TA-DF-BDM/ PSMA NPs exhibited such properties as red emission $\left(\lambda_{\mathrm{PL}}=610 \mathrm{~nm}\right)$, larger Stokes shift $(210 \mathrm{~nm})$, excellent photophysical stability in different $\mathrm{pH}$ value, good selectivity, low detection of $\mathrm{Fe}^{3+}$ ions $(0.9833 \mu \mathrm{mol} / \mathrm{L})$ in pure water. In PL spectra, the PL intensity of red emission peak of TA-DF-BDM/PSMA NPs degrades with increasing $\mathrm{Fe}^{3+}$ ions concentration. It is attributed to coordination reaction between $\mathrm{Fe}^{3+}$ ions and malononitrile of BDM unit in TA-DF-BDM, which can frustrate the twisting D- $\pi-A$ configuration and restrain red-emission originating from charge transfer from TA to BDM. Additionally, TA-DFBDM/PSMA NPs have good reversibility of fluorescence probes for detection of $\mathrm{Fe}^{3+}$ ions. By human serum measurements and cellular imaging, it can be found that TADF-BDM/PSMA NPs shows high analytical precision, good biocompatibility and low cytotoxicity. Above all, TA-DF-BDM/PSMA NPs exhibits a huge potential to be applied in biomedical practice. 


\section{Experimental}

\subsection{Synthetic section}

All reagents and organic solvents were purchased from commercial chemical reagent company and used without further purification. The synthetic route of TA-DF-BDM is shown in Figure 12.

4.1.1 Preparation of 4-(7-bromo-9,9-dioctylfluoren-2yl)- $N, N$-diphenylaniline (M1)

The triphenylamine 4-borate $(0.371 \mathrm{~g}, 1 \mathrm{mmol})$ and 9,9dioctyl-2,7-dibromofluorene (1.192 g, $2 \mathrm{mmol})$ were dissolved in $15 \mathrm{~mL}$ of toluene, and $\mathrm{K}_{2} \mathrm{CO}_{3}$ aqueous solution ( $2 \mathrm{~mol} / \mathrm{L}, 10 \mathrm{~mL}$ ) was dropped into it. Then, tetrakistriphenylphosphine palladium $\left(\mathrm{Pd}\left(\mathrm{PPh}_{3}\right)_{4}\right) \quad(0.057 \mathrm{~g}$, $0.05 \mathrm{mmol}$ ) was added into above reaction mixture. After refluxing for $4 \mathrm{~h}$ under nitrogen protection, the reaction mixture was poured into water and extracted with dichloromethane. The collected organic layer was dried over anhydrous $\mathrm{MgSO}_{4}$ and concentrated under reduced pressure. Finally, the resultant residue was purified by silica gel column chromatography using mixture eluents of ethyl acetate and hexane $(V: V=1: 20)$ to afford M1 as intermediate product, $0.3123 \mathrm{~g}, 74.2 \%$ yield. ${ }^{1} \mathrm{H}$ NMR $(600$ MHz, DMSO- $\left.d_{6}\right) \delta: 7.86(\mathrm{~d}, J=7.9 \mathrm{~Hz}, 1 \mathrm{H}), 7.77(\mathrm{~d}, J=$ $8.1 \mathrm{~Hz}, 1 \mathrm{H}), 7.72$ (d, $J=1.3 \mathrm{~Hz}, 1 \mathrm{H}), 7.64$ (ddd, $J=16.5$, 10.7, 8.7 Hz, 4H), $7.51(\mathrm{dd}, J=8.0,1.8 \mathrm{~Hz}, 1 \mathrm{H}), 7.36 \sim$ $7.29(\mathrm{~m}, 4 \mathrm{H}), 7.10 \sim 7.02(\mathrm{~m}, 8 \mathrm{H}), 2.04(\mathrm{tt}, J=13.3,8.3$ $\mathrm{Hz}, 4 \mathrm{H}), 1.25 \sim 0.95(\mathrm{~m}, 20 \mathrm{H}), 0.75(\mathrm{t}, J=7.2 \mathrm{~Hz}, 6 \mathrm{H})$, 0.49 (s, 4H). Anal. cald for $\mathrm{C}_{47} \mathrm{H}_{54} \mathrm{BrN}$ : C 79.22, H 7.59, $\mathrm{Br}$ 11.22, N 1.97; found C 79.17, H 7.72, Br 11.22, N 1.97.

4.1.2 Preparation of 4-(7-(4-(diphenylamino)phenyl)9,9-dioctylfluoren-2-yl)benzaldehyde (M2)

The intermediate product of M1 $(0.381 \mathrm{~g}, 0.5 \mathrm{mmol})$ and 4-acylphenylboronic acid $(0.234 \mathrm{~g}, 1 \mathrm{mmol})$ were dissolved in $15 \mathrm{~mL}$ of toluene, which mixed with $\mathrm{K}_{2} \mathrm{CO}_{3}$ aqueous solution $(2 \mathrm{~mol} / \mathrm{L}, 10 \mathrm{~mL})$. Then, $\mathrm{Pd}\left(\mathrm{PPh}_{3}\right)_{4}$ $(0.057 \mathrm{~g}, 0.05 \mathrm{mmol})$ was added into reaction mixture, which was been refluxing overnight under nitrogen protection. Then, the resulting mixture was poured into water and extracted with dichloromethane. The collected organic layer was dried over anhydrous $\mathrm{MgSO}_{4}$ and concentrated under reduced pressure. Finally, the resultant residue was purified by silica gel column chromatography using ethyl acetate and hexane $(V: V=1: 15)$ as eluents to afford $\mathbf{M 2}$ as intermediate product, $0.2308 \mathrm{~g}, 60.6 \%$ yield. ${ }^{1} \mathrm{H}$ NMR $\left(600 \mathrm{MHz}, \mathrm{CDCl}_{3}\right) \delta: 10.08(\mathrm{~s}, 1 \mathrm{H}), 8.00 \sim 7.96(\mathrm{~m}, 2 \mathrm{H})$, $7.85 \sim 7.82(\mathrm{~m}, 2 \mathrm{H}), 7.81 \sim 7.75(\mathrm{~m}, 2 \mathrm{H}), 7.64(\mathrm{dd}, J=7.9$, $1.7 \mathrm{~Hz}, 1 \mathrm{H}), 7.61 \sim 7.54(\mathrm{~m}, 5 \mathrm{H}), 7.30 \sim 7.27(\mathrm{~m}, 3 \mathrm{H}), 7.26$ $(\mathrm{d}, J=4.3 \mathrm{~Hz}, 1 \mathrm{H}), 7.20 \sim 7.13(\mathrm{~m}, 6 \mathrm{H}), 7.04(\mathrm{tt}, J=7.5$, $1.1 \mathrm{~Hz}, 2 \mathrm{H}), 2.08 \sim 1.98(\mathrm{~m}, 4 \mathrm{H}), 1.21 \sim 1.00(\mathrm{~m}, 20 \mathrm{H})$, $0.78(\mathrm{t}, J=7.2 \mathrm{~Hz}, 6 \mathrm{H}), 0.70(\mathrm{t}, J=10.6 \mathrm{~Hz}, 4 \mathrm{H})$. Anal. cald for $\mathrm{C}_{54} \mathrm{H}_{59} \mathrm{NO}$ : C 87.92, H 8.01, N 1.90, O 2.17; found C 87.75, H 8.12, N 1.90, O 2.17.

\subsubsection{Preparation of TA-DF-BDM}

The intermediate product of $\mathbf{M} 2(0.246 \mathrm{~g}, 0.33 \mathrm{mmol})$ and malononitrile $(0.066 \mathrm{~g}, 1 \mathrm{mmol})$ were dissolved into mixture solution of absolute ethanol $(15 \mathrm{~mL})$ and tetrahydrofuran (THF) $(5 \mathrm{~mL})$. The reaction mixture was keeping refluxing for $3 \mathrm{~h}$. Then, the solvent was concentrated under reduced pressure. Finally, The resultant residue was purified by silica gel column chromatography using ethyl acetate and hexane $(V: V=1: 15)$ as eluents to afford TADF-BDM as yellow solid powder $0.2206 \mathrm{~g}, 69.7 \%$ yield. m.p. 166.2 168.6 ${ }^{\circ} \mathrm{C} ;{ }^{1} \mathrm{H}$ NMR $\left(600 \mathrm{MHz}, \mathrm{CDCl}_{3}\right) \delta$ : $8.02(\mathrm{~d}, J=8.4 \mathrm{~Hz}, 2 \mathrm{H}), 7.85$ (t, $J=8.3 \mathrm{~Hz}, 2 \mathrm{H}), 7.81(\mathrm{t}$, $J=3.9 \mathrm{~Hz}, 2 \mathrm{H}), 7.78(\mathrm{~d}, J=7.9 \mathrm{~Hz}, 1 \mathrm{H}), 7.65(\mathrm{dd}, J=7.9$, $1.7 \mathrm{~Hz}, 1 \mathrm{H}), 7.62 \sim 7.54(\mathrm{~m}, 5 \mathrm{H}), 7.31 \sim 7.26(\mathrm{~m}, 4 \mathrm{H}), 7.17$ (ddd, $J=9.7,7.6,1.5 \mathrm{~Hz}, 6 \mathrm{H}), 7.07 \sim 7.03(\mathrm{~m}, 2 \mathrm{H}), 2.04$ $(\mathrm{dd}, J=9.7,6.8 \mathrm{~Hz}, 4 \mathrm{H}), 1.19 \sim 1.02(\mathrm{~m}, 20 \mathrm{H}), 0.78(\mathrm{t}, J=$ $7.2 \mathrm{~Hz}, 6 \mathrm{H}), 0.72 \sim 0.64(\mathrm{~m}, 4 \mathrm{H})$. Anal. cald for $\mathrm{C}_{57} \mathrm{H}_{59} \mathrm{~N}_{3}$ : C 87.13, H 7.51, N 5.35; found C 87.23, H 7.53, N 5.27.

\subsection{Preparation of nanoparticles of TA-DF-BDM/ PSMA}

As shown in Figure 13, the TA-DF-BDM/PSMA nanoparticles (named as TA-DF-BDM/PSMA NPs) were prepared by reprecipitation method. First, TA-DF-BDM and PMSA were dissolved into THF to obtain a solution with concentration of $10^{-3} \mathrm{~mol} / \mathrm{L}$. Then, $100 \mu \mathrm{L}$ of THF solution of TA-DF-BDM and PSMA $(5: 1, \mathrm{~m} / \mathrm{m})$ was added quickly to deionized water $(10 \mathrm{~mL})$ during ultrasonication.
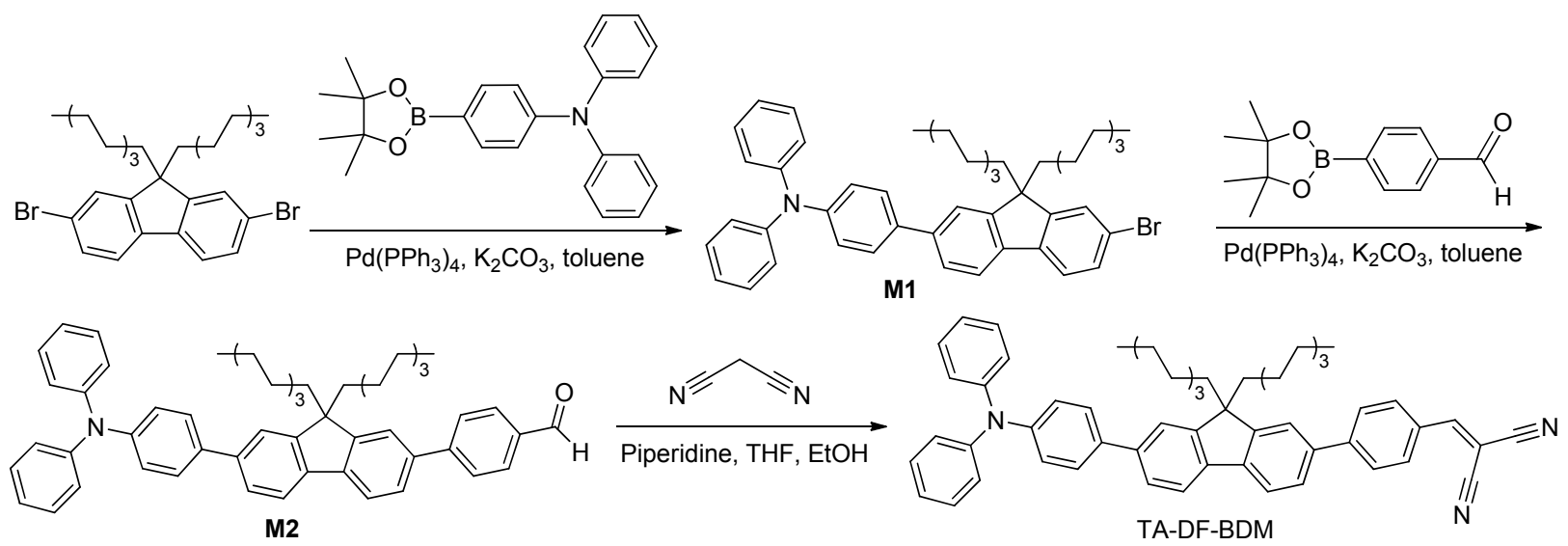

Figure 12 Synthetic route of TA-DF-BDM 


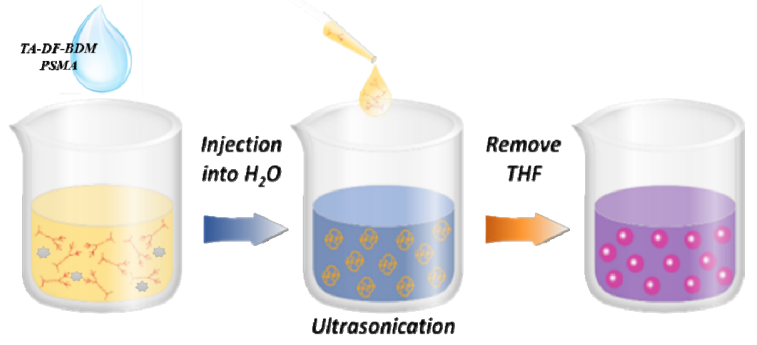

Figure 13 Illustration of preparation process of TA-DF-BDM/ PSMA NPs

The THF was removed by heating under nitrogen protection, followed by filtration through a $0.22 \mu \mathrm{m}$ aqueous phase needle filter. And, the resulting TA-DF-BDM/ PSMA NPs solution was acquired.

\subsection{Measurement section}

The aqueous solutions of $\mathrm{FeCl}_{3}, \mathrm{Zn}\left(\mathrm{NO}_{3}\right)_{2}, \mathrm{AgNO}_{3}$, $\mathrm{FeCl}_{2} \cdot 7 \mathrm{H}_{2} \mathrm{O}, \quad \mathrm{CoCl}_{2} \bullet 6 \mathrm{H}_{2} \mathrm{O}, \quad \mathrm{NaCl}, \mathrm{Pb}\left(\mathrm{NO}_{3}\right)_{2}, \quad \mathrm{HgCl}_{2}$, $\mathrm{Ni}\left(\mathrm{NO}_{3}\right)_{2} \bullet 6 \mathrm{H}_{2} \mathrm{O}, \mathrm{CdCl}_{2} \bullet 2.5 \mathrm{H}_{2} \mathrm{O}, \mathrm{MnSO}_{4}, \mathrm{BaCl}_{2}, \mathrm{CuSO}_{4} \bullet$ $5 \mathrm{H}_{2} \mathrm{O}, \mathrm{MgCl}_{2}, \mathrm{CaCl}_{2}, \mathrm{KCI}$, and $\mathrm{Al}\left(\mathrm{NO}_{3}\right)_{3} \cdot 9 \mathrm{H}_{2} \mathrm{O}$ with a concentration of $10^{-3} \mathrm{~mol} / \mathrm{L}$ were respectively prepared. Before spectral measurement, the high-concentration stock solution was diluted to the concentration required.

The ${ }^{1} \mathrm{H}$ NMR spectra were recorded by an AVANCE $600 \mathrm{MHZ}$ spectrometer. The infrared (IR) absorption spectra were measured using a Bruker TENSOR 27. The average diameter of TA-DF-BDM/PSMA NPs was determined by the dynamic light scattering (DLS, Malvern Zetasizer Nano ZS90). The morphology of TA-DF-BDM/PSMA NPs was investigated by transmission electron microscope (TEM) (JEOL JEM-2010, $200 \mathrm{KV}$ ). The ultraviolet-visible (UV-vis) absorption spectra were recorded on a Hitachi U-3900 scanning spectrophotometer. Fluorescence spectra were measured on a HORIBA FluoroMax-4 fluorescence spectrometer, and the fluorescence spectra were all excited by $365 \mathrm{~nm}$.

\subsection{MTT assay}

Cytotoxicity studies on TA-DF-BDM/PSMA NPs were performed using MTT assay. The HeLa Cells $\left(10^{6}\right.$ cell per $\mathrm{mL})$ were dispersed within replicate 96-well microtiter plates to a total volume of $200 \mathrm{~mL} /$ well. The plates were maintained at $37{ }^{\circ} \mathrm{C}$ in incubator with mixture gas of $\mathrm{CO}_{2}$ and air $(V: V=5: 95)$ for $4 \mathrm{~h}$. The TA-DF-BDM/PSMA NPs were diluted to different concentrations with medium and added to each well after removing original medium. HeLa cells were incubated with probe concentrations for $24 \mathrm{~h}$. The concentrations of the TA-DF-BDM/PSMA NPs were $2.5 \sim 30 \mu \mathrm{mol} / \mathrm{L}$, and $200 \mathrm{~mL}$ of MTT solution $(5.0$ $\mathrm{mg} \cdot \mathrm{mL}^{-1}$, HEPES) was added to each well. After $4 \mathrm{~h}$, the remaining MTT solution was removed, and $150 \mathrm{~mL}$ of DMSO was added into each well to dissolve the formazan crystals. Absorbance was measured at $610 \mathrm{~nm}$ in a TRITURUS (Bio-Rad, Model 550) microplate reader.

\subsection{Cell research}

The HeLa cells were cultured in DMEM medium sup- plemented with $10 \%$ FBS (fetal bovine serum) at $37{ }^{\circ} \mathrm{C}$ in a humidified environment of $5 \% \mathrm{CO}_{2}$. The cells were plated on 6 -well plates at $5 \times 10^{4}$ cells per well and allowed to adhere for $12 \mathrm{~h}$. TA-DF-BDM/PSMA NPs $(0.5$ $\mu \mathrm{L}, 10 \mu \mathrm{mol} / \mathrm{L})$ were added to the cell medium $(500 \mu \mathrm{L})$ at $10 \mathrm{mmol} / \mathrm{L}$ final concentration. After incubating for 60 min, excess TA-DF-BDM/PSMA NPs were removed by gentle rinsing with cold phosphate buffer saline (PBS, $\mathrm{pH}=7.4$ ) three times. Then, the cells pretreated with TADF-BDM/PSMA NPs were treated with $\mathrm{Fe}^{3+}(50 \mu \mathrm{mol} / \mathrm{L})$ in DMEM medium, incubated for further $30 \mathrm{~min}$ at $37{ }^{\circ} \mathrm{C}$ and washed with PBS buffer. Fluorescence images were collected by sequential line scanning using the Olympus FV1000 confocal laser-scanning microscope. Fluorescence images were recorded at red channels $(550 \sim 650 \mathrm{~nm})$.

Supporting Information ${ }^{1} \mathrm{H}$ NMR spectrum of M1, M2 and TA-DF-BDM, ${ }^{13} \mathrm{C}$ NMR spectrum of TA-DF-BDM in $\mathrm{CDCl}_{3}$, IR and ESI-MS spectra of TA-DF-BDM. Elements composites of M1 and M2, the high resolution ESI-mass spectrum of TA-DF-BDM, the change of the solution fluorescence intensity adding the $\mathrm{Fe}^{3+}$ ion under variety of the $\mathrm{pH}$ and the reducibility of glutathione at different concentrations.

\section{References}

[1] Atchudan, R.; Edison, T. N. J. I.; Aseer, K. R.; Perumal, S.; Karthik, N.; Lee, Y. R. Biosens. Bioelectron. 2018, 99, 303.

[2] Li, Y.; Chang, Z. L.; Huang, F.; Wu, P. Y.; Chu, H. C.; Wang, J. Dalton Trans. 2018, 47, 9267.

[3] Choi, Y. W.; Park, G. J.; Na, Y. J.; Jo, H. Y.; Lee, S. A.; You, G. R.; Kim, C. Sens. Actuators, B 2014, 194, 343.

[4] Chen, L.; Wu, C. L.; Du, P.; Feng, X. W.; Wu, P.; Cai, C. X. Talanta 2017, 164, 100 .

[5] Kaur, K.; Chaudhary, S.; Singh, S.; Mehta, S. K. Sens. Actuators, B 2016, 232, 396.

[6] Ghosh, D.; Luwang, M. N. J. Lumin. 2016, 171, 1.

[7] Sharma, D.; Kuba, A.; Thomas, R.; Kumar, R.; Choi, H. J.; Sahoo, S. K. Spectrochim. Acta, Part A 2016, 153, 393.

[8] Liu, F. J.; Yao, J.; Fan, C.; Zhang, L. Y.; Hua, Y; Zhang. C. X; Song, N.; Kong, Y. J. New J. Chem. 2018, 42, 9676.

[9] Lee, M. H.; Kim, J. S.; Sessler, J. L. Chem. Soc. Rev. 2015, 44 4185.

[10] Ma, J.; Yu, H. H.; Jiang, X.; Luo, Z. Z.; Zheng, Y. Sens. Actuators, B 2019, 281, 989.

[11] Liu, Y. H.; Duan, W. X.; Song, W.; Liu, J. J.; Ren, C. L.; Wu, J.; Liu, D.; Chen, H. L. ACS Appl. Mater. Interfaces 2017, 9, 12663.

[12] Rao, L. S.; Tang, Y.; Li, Z. T.; Ding, X. R.; Liang, G. W.; Lu, H. G.; Yan, C. M.; Tang, K. R.; Yu, B. H. Mater. Sci. Eng., C 2017, 81, 213.

[13] Wu, S.; Chen, Y.; Sung, Y. Analyst 2018, 99, 303.

[14] Feng, H.; Meng, Q. T.; Wang, Y.; Duan, C. C.; Wang, C. P.; Jia, H. M.; Zhang, Z. Q.; Zhang, R. Chem.-Asian. J. 2018, 13, 2573.

[15] Asanuma, D.; Sakabe, M.; Kamiya, M.; Yamamoto, K.; Hiratake, J.; Ogawa, M.; Kosaka, N.; Choyke, P. L.; Nagano, T.; Kobayashi, H. Nat. Commun. 2015, 6, 6463.

[16] Chhatwal, M.; Kumar, A.; Singh, V.; Gupta, R. D.; Awasthi, S. K. Coord. Chem. Rev. 2015, 292, 30.

[17] Tao, P.; Miao, Y. Q.; Wang, H.; Xu, B. S.; Zhao, Q. Chem. Rec. 2019, 19, 1531.

[18] Xing, J.; Liu, D.; Zhou, G. X.; Li, Y.; Wang, P.; Hu, K.; Gu, N.; Ji, M. Colloids Surf., B 2017, 160, 265. 
[19] Liu, Y. M.; Shen, R.; R, J. X.; Yao, X.; Yang, Y.; Liu, H. L.; Tang, X. L.; Bai, D. C.; Zhang, G. L; Liu, W. S. RSC $A d v$. 2016, 6, 111754.

[20] Manikandan, I.; Chang, C. H.; Chen, C. L.; Sathish, V.; Li, W. S.; Malathi, M. Spectrochim. Acta, Part A 2017, 182, 58

[21] Jung, H. J.; Singh, N.; Jang, D. O.; Tetrahedron Lett. 2008, 49, 2960.

[22] Wang, P.; Zhou, D. G.; Chen, B. Spectrochim. Acta, Part A 2019, 207, 276.

[23] Feng, X.; Li, Y.; He, X. W.; Liu, H. X.; Zhao, Z.; Ryan, T. K. K.; Mark, R. J. E.; Jaeky, W. Y.; Lam, J. W. Y.; Tang, B. Z. Adv. Funct. Mater. 2018, 28, 1802833.

[24] Yang, C. C; Zhang, J.; Peng, W. T.; Sheng, W.; Liu, D. Y.; Kuttipillai, P. S.; Young, M.; Donahue, M. R.; Levine, B. G; Borhan, B.; Lunt, R. R. Sci. Rep. 2018, 8, 16359.

[25] Wang, N.; Arulkumar, M.; Chen, X. Y.; Wang, B. W.; Chen, S. H.; Yao, C.; Wang, Z. Y. J. Org. Chem. 2019, 39, 2771 (in Chinese). (王能, Arulkumar, M., 陈孝云, 王柏文, 陈思鸿, 姚辰, 汪朝阳,
有机化学, 2019, 39, 2771.)

[26] Feng, Z. Y; Tao, P.; Zou, L.; Gao, P. L.; Liu, Y.; Liu, X.; Wang, H.; Liu, S. J.; Dong, Q. C.; Li, J.; Xu, B. S; Huang, W.; Wong, W. Y.; Zhao, Q. ACS Appl. Mater. Interfaces 2017, 9, 28319.

[27] Zhang, Z. Y.; Lu, S. Z.; Sha, C. M.; Xu, D. M. Sens. Actuators, B 2015, 208, 258.

[28] Wan, Q. Q.; Chen, S. M.; Shi, W.; Li, L. H.; Ma, H. M. Angew. Chem., Int. Ed. 2014, 53, 10916.

[29] Jiang, M. J.; Gu, X. G.; Lam, J. W. Y.; Zhang, Y. L.; Kwok, R. T. K.; Wong, K. S.; Tang, B. Z. Chem. Sci. 2017, 8, 5440.

[30] Yang, X. D; Chen, X. L; Lu, X. D.; Yan, C. G.; Xu, Y. K.; Hang, X. D.; Qu, J. Q.; Liu, R. Y. J. Mater. Chem. 2016, 4, 383.

[31] Wang, L. Y.; Fang, G. P.; Cao, D. R. Sens. Actuators, B 2015, 207, 849.

[32] Wu, X. M.; Guo, Z. Q.; Wu, Y. Z.; Zhu, S. Q.; Tony, D. J.; Zhu, W. H. ACS Appl. Mater. Interfaces 2013, 5, 12215.

[33] Shi, B. F.; Su, Y. B.; Zhang, L. L.; Huang, M. J.; Liu, R. J.; Zhao, S. L. ACS Appl. Mater. Interfaces 2016, 8, 10717.

(Cheng, F.) 